
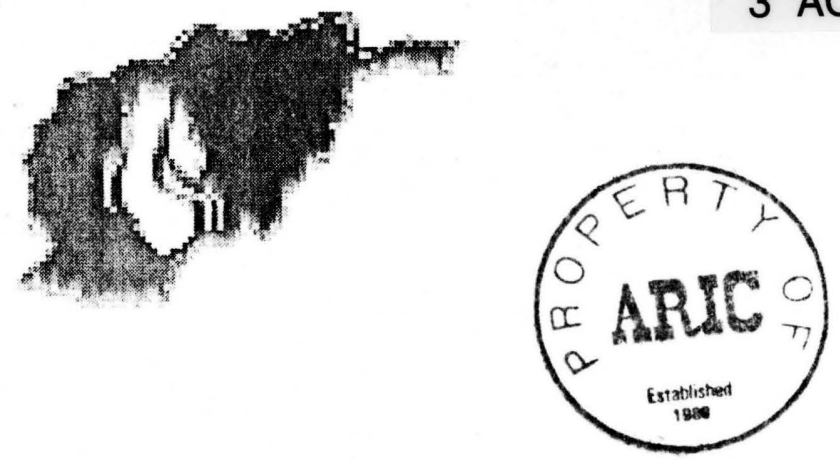

\title{
Afghanistan Women Council
}

(i. P. O. Box 1215. Peshawar, Pakistan

Office: 56 Str. 10, Sector L-I. Phase II, Hayatabad, Peshawar, Pakistan

Tel.: $0092-91-812115$ Fax: $0092-91-812138$

E-Mail: gillania awc.pwr.sdnpk.undp.org

\section{Trip to Italy Report}

$$
\text { May 6-31, 2001 }
$$

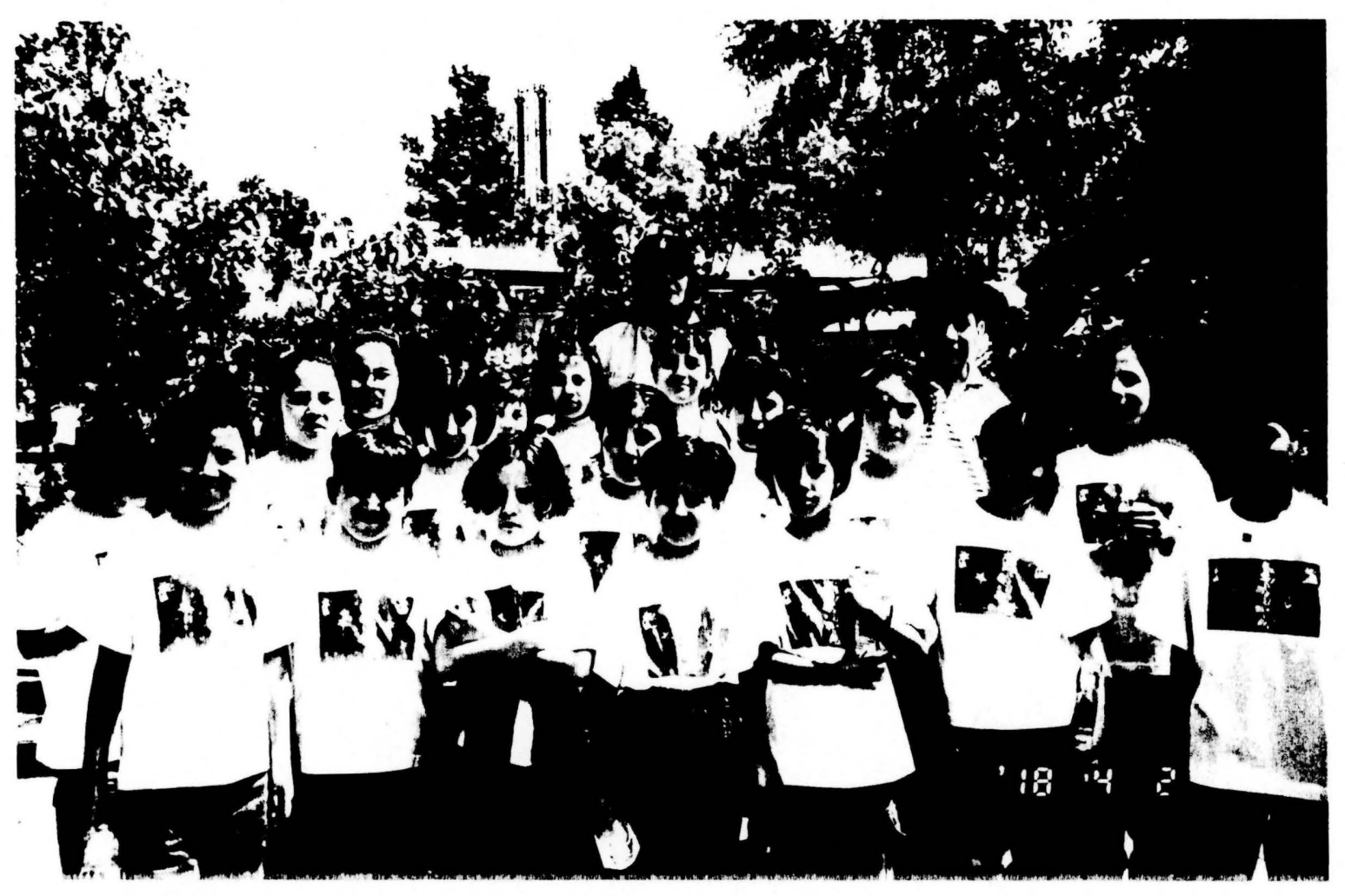

Prepared by: Fatama Ishat Gailani Date: 15 .June 2001

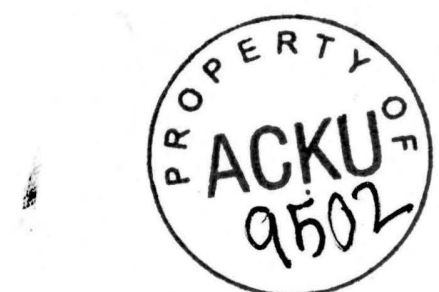


June 15, 2001

To: $\quad$ AWC members and volunteers

From: $\quad$ Fatana Ishaq Gailani

Director AWC

CC: $\quad$ Pavarotti and Friends, UNHCR Peshawar, UNHCR Islamabad, UNSMA Islamabad, UNHCR Rome, UNHCR USA, Amnesty International Japan, Amnesty International Spain, Amnesty International UK, Amnesty International USA, Human Rights Alliance USA, Human Rights Watch USA

Subject: Inip to Italy Report

Purpose of the trip:

- Participation of 35 Afghans in a concert given by Mr. Luciano Pavarotti and friends in Modena, Italy to benefit Afghan refugees living in Pakistan.

Participants: A group of 30 children (15 boys and 15 girls between the ages of 7 to 12 ) and 5 adults

Itinerary:

May 6, 2001. Arrival in Rome, Italy via KRAS AIR, a special flight from Peshawar airport.

May 7, 2001. The group joined all the agencies participating in carrying out this project in a press conference hosted by RAIUNO.

The group met the former king of Afghanistan, His Excellency Mr. Zahir Shah, and his family members.

May 8, 2001. The group left for Parma.

May 9-29, 2001. The group stayed at "Castello di Castelnuovo Fogliani" and was busy in different activities such as:

- Music classes with the Italian children's choir and Ms. Sylvia.

- $\quad$ Entertainment e.g. trips to Mirabilandia, McDonald's and Parco Natura Viva etc.

- Press interviews with journalists from different radio stations, television channels, magazines and newspapers e.g. Swiss Radio, RAIUNO and ANNA.

The benefit concert was held on the $29^{\text {th }}$ of May in Modena, Parco Novi Sad. It lasted from 21:00-24:30.

May 30, 2001. The group left for Rome, arriving in Islamabad, Pakistan via PIA.

May 31, 2001. The group left Islamabad for Peshawar. 


\section{Pavarotti and friends for Afghanistan}

Mr. Luciano Pavarotti, the world famous Italian singer, held a concert in Modena, Italy on the $29^{\text {th }}$ of May 2001. The concert was the most recent one of a series of benefit concerts he has held in the past few years. The concert was arranged under the supervision of UNHCR and with the help of organizations such as "ARTE", "il Resto del Carlino LA NAZIONE IL GIORNO", "RANA", "MONTE DEI PASCHI DI SIENA", BANCA DAL1472", "RAIUNO", "FUTUR SHOW", "RADIO BRUNO", "CAMST" and "RADIO Dimmenzione Suono".

A group of thirty Afghan children - fifteen boys and fifteen girls between the ages of seven to twelve-- were to be chosen to participate in this concert. Five adults who could mange the trip and accept responsibility for this part of the mission were also required. Officials of UNHCR, with the help of the AWC, selected the group of 30 children and 5 adults from Aryana High School and the AWC.

This concert was held for the benefit of Afghan refugees living in camps inside Pakistan. Over one million US dollars were raised. This aid will be administered through the different emergency relief and long-term self-sufficiency projects of UNHCR.

\section{Conclusions:}

This trip was very successful because of the large amount of money donated to the Afghan refugees in Pakistan and the publicity generated in the international community concerning the issue of Afghanistan, which has been neglected.

It was also a treat for the group to visit our former king, whom most of the country's people believe will be able to bring peace and security to Afghanistan via the Loya Jerga (traditional Afghan council) and the eventual establishment of a stable and elected government.

On behalf of all the members of the Afghanistan Women Council, Ms. Fatana Gailani would like to convey her gratitude to Pavarotti and Friends for Afghanistan, UNHCR, the Government of Italy, the families of the Afghan children and their caretakers and all those organizations that helped in arrangements for such a fantastic concert. The funds raised are timely and will be very helpful in protecting the lives of thousands of dependent Afghan children and mothers.

Afghanistan Women Council thanks UNHCR for the honor of selection for participation in this joint project in fundraising for Afghan refugees. AWC is proud of the successful completion of the project and will be happy to contribute in the future to such projects to help the Afghans.

\section{Background}

\section{Afghanistan Women Council (AWC)}

Afghan women, who constitute half of the country's population, have always had an important role in the struggle for freedom. The heroic struggle of Afghan women in the first and second war against the British invaders and then against the Russian invaders in various part of Afghanistan has become a glorious part of our history.

Since the women of Afghanistan suffered more than anybody else during the resistance against the Taliban, it is deemed necessary to take proper measures to address their problems and make sure that they, like their brothers and fathers, have access to their basic needs, and their voice can reach those to 
3,700,000 of which about 2 million are in Pakistan. More than half of them are children less than 17 years of age. The Jalozai and Shamshatoo refugee camps are arenas of human tragedy. In Iran the official number of Afghan refugees is about a million and a half but hundreds of thousands live there without having registered. Tens of thousands of Afghan refugees are scattered throughout the rest of the world.

The international community has turned its back on the Afghan situation and has allowed Afghanistan to become the center of human rights violations and terrorism. Foreign interference is increasing with the passage of every single day and the Afghans are becoming less and less involved in decision-making and even finding solutions to their national issues. The indifference of the international community towards clear-cut violations of human rights in Afghanistan and towards the conditions of refugees is itself a deprivation of the Afghan people. At present, there is no legal framework within which Afghan peoples' rights could be ascertained.

The AWC, following its policy of peace and logic, has used different ways to persuade the warning factions and especially the Taliban to come to the negotiation table and discuss all national issues including the human rights issue of women in a peaceful atmosphere. We will continue to work in various ways to secure the rights of the women and children of Afghanistan. 
whom the future of our society belongs. To materialize these hopes, we, a number of patriotic women led by Ms. Fatana Gailani, established the Afghanistan Women Council (AWC) in 1993 to achieve the rights of the Afghan women in our country. AWC presently has 105 paid staff and 26 volunteers.

The aim/mission of the Afghanistan Women Council are:

- To secure the civil and social rights of women in accordance with Islamic principles and in line with the culture and traditions of Afghanistan.

- To improve the economic, health and cultural conditions of Afghan women and children.

- To provide opportunities for the active participation of women, within Islamic law and Afghan culture, in educating the next generation, and in the rehabilitation and development of Afghan society through capacity building.

- To convince the warring factions to respect the basic rights of Afghan women and allow them to participate in national politics and participate in government administration.

- To encourage the warring factions to put away their differences and join hands for national unity and reconstruction of Afghanistan.

The Afghanistan Women Council makes every endeavor to secure these objectives and is not affiliated with any political party.

\section{Situation of Afghans in Afghanistan and as refugees in Pakistan}

For more than twenty years Afghanistan has been wracked by conflicts, a grave consequence of which has been the tremendous number of refugees scattered all over the world, especially in those countries sharing a frontier with Afghanistan itself. In 1979 Soviet troops invaded the country and established a military occupation, which lasted for about ten years. But even after their retreat the country found no lasting peace as outbreaks of civil strife tore it apart, with warring Mujahideen factions battling for superiority after having fought against their occupiers in previous years.

In 1994 the Taliban movement, constituting students of the Islamic school situated in Pakistan, arose in Afghanistan and in 1996 took power in the capital city Kabul. In subsequent years, the Taliban gained power over 90 percent of the country and imposed a rigid interpretation of the Islamic law Sharia, prohibiting any kind of public life for women. At present, no legitimate government or proper governance exists in Afghanistan.

The people of Afghanistan, especially the women, have been the worst victims of war and human rights violations of the $20^{\text {th }}$ century. The people are at the mercy of local groups and commanders who issue decrees on every issue. Human rights violations were committed by the Mujahideen commanders and continue to be perpetrated by the Taliban and warring factions inside Afghanistan. The Afghan people have been completely stripped of the freedom of speech and engagement in political activities. For those who work for the restoration of peace, human rights, security, democracy and national unity, the word safety has lost its meaning as they have been either assassinated or are under threats of various kinds. Many are therefore forced to take refuge in other countries. However, those who fled Afghanistan continue to face severe threats in exile.

More than 22 years of conflict and the recent drought have made Afghanistan the country from which the greatest numbers of refugees have fled. The lives of recent refugees are especially threatened by poverty, hunger, lack of shelter and other problems. Today Afghan refugees number

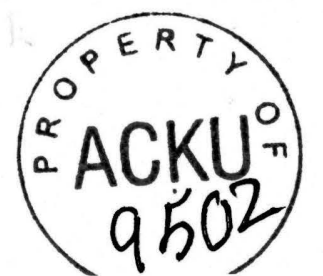

